\title{
Hubungan antara Volume Residu Gaster dan Skor Glasgow Coma Scale (GCS) pada Pasien Cedera Otak Traumatik Sedang dan Berat
}

\author{
Cindy Giovanni, Dewi Yulianti Bisri, Tatang Bisri \\ Departemen Anestesiologi dan Terapi Intensif \\ Fakultas Kedokteran Universitas Padjadjaran/ RSUP Dr. Hasan Sadikin Bandung
}

\begin{abstract}
Abstrak
Latar Belakang dan Tujuan: Cedera Otak Traumatik (COT) berhubungan dengan disfungsi gastrointestinal berupa perlambatan pengosongan lambung. Belum jelas adakah hubungan antara skor Glasgow Coma Scale (GCS) dan derajat gangguan pengosongan lambung yang terjadi. Penelitian ini bertujuan untuk membandingkan volume residu gaster pada pasien COT sedang dan berat serta mengkaji hubungan antara skor GCS dan volume residu gaster pada pasien COT.

Subjek dan Metode: Penelitian observasional analitik cross-sectional ini dilakukan pada 42 pasien COT sedang dan berat yang dirawat di RSUP Dr. Hasan Sadikin dari bulan Desember 2016 hingga Juni 2017. Pengukuran volume residu gaster, skor GCS, dan tanda vital dilakukan tiap 6 jam selama 48 jam. Data hasil penelitian diuji dengan uji t tidak berpasangan, Chi Square, dan uji korelasi Pearson.

Hasil: Hasil penelitian menyatakan bahwa rerata volume residu gaster pada kelompok COT sedang dan berat adalah $10,83 \pm 8,15 \mathrm{ml}$ dan $50,59 \pm 18,23 \mathrm{ml}$ (p 0,000). Korelasi antara skor GCS dan volume residu gaster menunjukkan adanya korelasi negatif yang bermakna dan sangat kuat $(\mathrm{r}=-0,745$ hingga -,974; $\mathrm{p}=0,000)$.

Simpulan: Volume residu gaster pada COT berat lebih banyak dari COT sedang dan terdapat hubungan antara skor GCS dan volume residu gaster pada pasien COT.
\end{abstract}

Kata kunci: cedera otak traumatik sedang, cedera otak traumatik berat, glasgow coma scale, volume residu gaster

JNI 2018;7 (1): 11-6

\section{Correlation between Gastric Residual Volume and Glasgow Coma Scale (GCS) Score in Patient with Moderate and Severe Traumatic Brain Injury}

\begin{abstract}
Background and Objective: Traumatic Brain Injury (TBI) is associated with gastrointestinal dysfunction in the form of delayed gastric emptying. It is not clear whether there is a relationship between Glasgow Coma Scale (GCS) score and the degree of gastric emptying that occurs. This study aimed to compare gastric residual volume in moderate and severe TBI patients and to examine the relationship between GCS score and gastric residual volume in TBI patients.

Subject and Methods: This cross-sectional analytical observational study was conducted on 42 moderate and severe TBI patients who were admitted to Dr. Hasan Sadikin from December 2016 to June 2017. Measurement of gastric residual volume, GCS score, and vital signs were performed every 6 hours for 48 hours. The result data were tested with unpaired t-test, Chi Square, and Pearson correlation test.

Results: The results showed that the mean gastric residual volume in moderate and severe TBI groups was $10.83 \pm$ $8.15 \mathrm{ml}$ and $50.59 \pm 18.23 \mathrm{ml}(\mathrm{p} 0.000)$. The correlation between GCS and gastric residual volume showed a very strong negative correlation $(\mathrm{r}=-0,745$ to,$- 974 ; \mathrm{p}=0,000)$.

Conclusion: Gastric residual volume in patient with severe TBI is more than gastric residual volume in moderate TBI and there was a relationship between GCS score and gastric residual volume in TBI patients.
\end{abstract}

Key words: moderate traumatic brain injury, severe traumatic brain injury, glasgow coma scale, gastric residual volume

JNI 2018;7 (1): 11-6 


\section{Pendahuluan}

Cedera otak traumatik(COT) berhubungan dengan disfungsi gastrointestinal berupa perlambatan pengosongan lambung dan peningkatan refluks yang mengakibatkan intoleransi pemberian nutrisi enteral. ${ }^{1-4}$ Pada $50 \%$ pasien dengan COT derajat berat terjadi intoleransi pemberian nutrisi enteral hingga 15 hari setelah kejadian. ${ }^{5}$ Mekanisme disfungsi gastrointestinal pada pasien dengan COT berhubungan dengan peningkatan katekolamin yang menurunkan aliran darah ke gaster sehingga mengakibatkan iskemi mukosa gastrointestinal, gangguan motilitas gastrointestinal, gangguan integritas barier usus akibat peningkatan permeabilitas gastrointestinal, dan perubahan mukosa intestinal yang mengakibatkan penurunan fungsi absorpsi. ${ }^{3,6,7}$

Skor Glasgow Coma Scale (GCS) yang rendah berhubungan dengan makin meningkatnya kadar katekolamin yang dilepaskan. Pada beberapa penelitian, hiperaktivitas simpatis terjadi setelah COT berat. ${ }^{8,9}$ Semakin tinggi katekolamin yang dilepaskan, semakin rendah perfusi pada sistem gastrointestinal sehingga terjadi disfungsi gastrointestinal. ${ }^{10}$ Disfungsi gastrointestinal mengakibatkan peningkatan jumlah volume residu gaster. ${ }^{11,12}$ Tujuan penelitian ini adalah untuk membandingkan volume residu gaster pada pasien COT sedang dan berat serta mengkaji hubungan antara skor GCS dan volume residu gaster pada pasien COT.

\section{Subjek dan Metode Penelitian}

Penelitian ini bersifat observasional analitik cross-sectional. Subjek penelitian adalah 42 pasien COT yang dirawat konservatif di RSUP Dr. Hasan Sadikin. Penelitian ini dilakukan dari bulan Desember 2016-Juni 2017. Kriteria inklusi meliputi GCS 3-12, usia 18-60 tahun, waktu makan terakhir minimal 6 jam sebelum dibawa ke rumah sakit, body mass index (BMI) $18,5-25 \mathrm{~kg} / \mathrm{m}^{2}$. Kriteria eksklusi adalah trauma di tempat lain, riwayat penyakit gastrointestinal dan penyakit sistemik lain (diabetes mellitus, hipertensi, dan lain-lain), serta mendapatkan pengobatan yang memengaruhi pengosongan lambung (metoklopramid, atropin, inhibitor pompa proton, kortikosteroid, opioid kontinu). Pasien dikeluarkan dari penelitian bila pasien meninggal dalam rentang waktu pengambilan data. Jumlah sampel dihitung sesuai dengan tujuan dan tipe penelitian dengan taraf kepercayaan $95 \%$ dan power test $90 \%$ dan didapatkan jumlah seluruh sampel adalah 42 orang. Pemilihan subjek penelitian berdasarkan consecutive sampling, yaitu mengambil setiap subjek penelitian yang memenuhi kriteria inklusi dan eksklusi berdasarkan urutan kedatangan pasien. Subjek penelitian dibagi berdasar atas GCS menjadi 2 kelompok, yaitu kelompok COT sedang (GCS 9-12) dan berat (GCS 3-8) masingmasing berjumlah 21 orang. Setelah mendapatkan persetujuan dari Komite Etik Penelitian Kesehatan RSUP Dr. Hasan Sadikin Bandung/Fakultas Kedokteran Universitas Padjadjaran, pasien yang memenuhi kriteria inklusi dan eksklusi dipasang pipa nasogastrik, cairan lambung diaspirasi dengan spuit $50 \mathrm{ml}$ (catheter tip), dan diukur secara berkala setiap 6 jam hingga 48 jam. Selain volume residu gaster, GCS dan tanda vital pasien juga dicatat. Semua pasien pada penelitian ini diberikan analgetik Paracetamol $3 \times 1$ gram intravena untuk analgetika.

Data yang diperoleh dicatat dalam formulir khusus kemudian diolah dengan program Statistical Product \& Service Solution (SPSS) versi 21.0 for Windows. Uji kemaknaan untuk membandingkan karakteristik dua kelompok penelitian digunakan uji Mann Whitney. Analisis statistik untuk data kategorik diuji dengan uji chi-square. Uji korelasi dilakukan dengan uji Spearman dan Eta. Interpretasi hasil uji hipotesis berdasarkan kekuatan korelasi, arah korelasi, dan nilai $\mathrm{p}$ berdasarkan kriteria Guillford yaitu : 0,0 $<0,2=$ sangat lemah; $0,2-<0,4=$ lemah; $0,4-<0,7=$ sedang; $0,7-<0,9=$ kuat; $0,9-1,0=$ sangat kuat.

\section{Hasil}

Kedua kelompok penelitian tidak memiliki perbedaan karakteristik usia, jenis kelamin, BMI, dan diagnosis yang bermakna berdasarkan statistika ( $>00,05$; Tabel 1). Volume residu gaster 
pada pasien COT berat lebih banyak secara signifikan dari waktu ke waktu dan menunjukkan hubungan yang sangat kuat antara skor GCS dan volume residu gaster (Gambar 1 dan Tabel 2).

\section{Pembahasan}

Pemberian nutrisi pada pasien COT terutama COT berat memberikan tantangan tersendiri karena $44-100 \%$ pasien dengan COT berat mengalami disfungsi gastrointestinal yang ditandai dengan peningkatan volume residu gaster. ${ }^{13}$ Sampai saat ini belum ada penelitian yang secara langsung mengukur dan membandingkan volume residu gaster pada pasien COT namun beberapa penelitian menyatakan bahwa pada pasien dengan
COT sedang dan berat mengalami gangguan pengosongan lambung yang ditandai dengan peningkatan volume residu gaster. ${ }^{4,5}$

Penelitian pada tahun 1991 terhadap 12 pasien COT sedang dan berat (GCS 4-10) menyatakan bahwa dalam 2 minggu pertama terjadi gangguan pengosongan lambung dan intoleransi pemberian nutrisi enteral. ${ }^{5}$ Penelitian lain dilakukan dengan membandingkan waktu pengosongan lambung pada 35 pasien usia 25-52 tahun antara COT sedang dan berat (GCS 3-12) dan orang normal. Pengosongan lambung pada pasien dengan COT sedang dan berat memanjang secara signifikan. ${ }^{4}$

Volume residu gaster rerata pada pasien penelitian

Tabel 1 Karakteristik Subjek Penelitian

\begin{tabular}{llll}
\hline \multirow{1}{*}{ Variabel } & \multicolumn{3}{c}{ Kelompok } \\
\cline { 2 - 4 } & \multicolumn{1}{c}{$\begin{array}{c}\text { COT Sedang } \\
\mathrm{N}=21\end{array}$} & \multicolumn{1}{c}{$\begin{array}{c}\mathrm{N}=21 \\
\text { Nilai P }\end{array}$} \\
\hline $\begin{array}{l}\text { Usia (tahun) } \\
\text { Mean } \pm \text { Std }\end{array}$ & $39,95 \pm 17,220$ & $38,23 \pm 15,648$ & 0,772 \\
Jenis kelamin & & & \\
Laki-laki & $13(61,9 \%)$ & $13(61,9 \%)$ & 1,000 \\
Perempuan & $8(38,1 \%)$ & $8(38,1 \%)$ & \\
BMI & & & \\
Mean \pm Std & $21.42 \pm 1.426$ & $21.31 \pm 1.554$ & 0,052 \\
Median & 21.069 & 21.093 & \\
Range (min-max) & $18.55-23.88$ & $18.37-24.22$ & \\
& & & \\
Diagnosis & & & \\
Contusio serebri & $12(57,1 \%)$ & $10(47,6 \%)$ & \\
SAB dan contusio & $5(23,8 \%)$ & $6(28,6 \%)$ & \\
serebri & & $5(23,8 \%)$ & \\
SAH dan contusio & $4(19,0 \%)$ & & \\
serebri & & & \\
\hline
\end{tabular}

Keterangan: Untuk data numerik nilai p diuji dengan uji T tidak berpasangan apabila data berdsitribusi normal dengan alternatif uji Mann Whitney apabila data tidak berdistribusi normal. Data kategorik nilai p dihitung berdasarkan uji Chi-Square dengan alternatif uji Kolmogorov Smirnov dan Exact Fisher apabila syarat dari Chi-Square tidak terpenuhi. Nilai kemaknaan berdasarkan nilai $\mathrm{p}<0,05$. Tanda* menunjukkan nilai $\mathrm{p}<0,05$ artinya signifkan atau bermakna secara statistik. 


\section{Volume Residu Gaster}

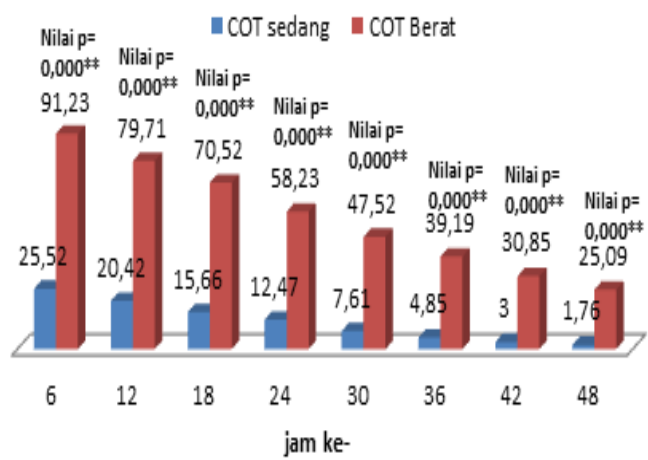

Gambar 1 Grafik Volume Residu Gaster pada Pasien COT Sedang dan Berat

ini adalah 30,71+13,19 $\mathrm{mL}$ tanpa diberikan nutrisi. Secara normal, gaster memproduksi sekitar 2 liter sekret setiap hari, namun saat puasa (periode interdigestif), hanya sedikit (beberapa mililiter) atau bahkan tidak ada sekret yang diproduksi. ${ }^{14,15}$ Sebuah penelitian tentang volume residu gaster saat puasa dilakukan di Afrika Selatan terhadap 430 pasien usia 10-90 tahun dengan hasil volume residu gaster rerata pada pasien normal, esofagitis/gastritis, ulkus gaster, dan ulkus duodenum yaitu 55,2+3,2 cc, 53,2+8,2 $\mathrm{ml}, 70+7,4 \mathrm{ml}$, dan $78,5+4,0 \mathrm{ml}^{16}$

Penelitian kohort retrospektif di Belgia dilakukan pada 583 pasien yang akan dilakukan pembedahan elektif dan dipuasakan sesuai dengan panduan puasa didapatkan volume residu gaster 18,8+18,7 $\mathrm{ml}$ pada 351 orang, $65,3+30,2 \mathrm{ml}$ pada 125 orang dan $138,1+33,6 \mathrm{ml}$ pada 27 orang. ${ }^{17}$ Hasil volume residu gaster pada penelitian tersebut lebih banyak dibanding dengan penelitian ini.

Perbedaan hasil ini dapat disebabkan oleh faktor pasien dan faktor peneliti. Pada penelitian di Afrika, terdapat perbedaan populasi dengan usia 10-90 tahun tanpa memperhitungkan penyakit penyerta lain selain penyakit saluran pencernaan, sedangkan pasien di Belgia merupakan pasien operasi elektif dalam keadaan sadar, yang mungkin saja mengalami stress sebelum pembedahan sehingga mengakibatkan peningkatan volume residu gaster, selain itu obat-obatan yang didapatkan pada kedua penelitian tersebut tidak dicantumkan, karena
Tabel 2 Hubungan antara GCS dan Volume Residu Gaster pada Pasien COT Sedang dan Berat

\begin{tabular}{llll}
\multirow{2}{*}{$\begin{array}{l}\text { H u b u n g a n } \\
\text { antara GCS } \\
\text { dan Volume }\end{array}$} & & & \\
$\begin{array}{c}\text { Residu Gaster } \\
\text { Jam ke }\end{array}$ & & & \\
& & & \\
\cline { 2 - 4 } & $\begin{array}{l}\text { COT } \\
\text { Sedang }\end{array}$ & $\begin{array}{l}\text { COT } \\
\text { Berat }\end{array}$ & Nilai P \\
\hline 6 & $-0,974$ & $-0,930$ & 0,000 \\
12 & $-0,971$ & $-0,923$ & 0,000 \\
18 & -0.977 & $-0,938$ & 0,000 \\
24 & $-0,931$ & $-0,918$ & 0,000 \\
30 & $-0,919$ & $-0,858$ & 0,000 \\
36 & $-0,890$ & $-0,823$ & 0,000 \\
42 & $-0,777$ & $-0,834$ & 0,000 \\
48 & $-0,745$ & $-0,955$ & 0,000 \\
\hline
\end{tabular}

mungkin saja pasien mengkonsumsi obatobatan yang meningkatkan sekresi lambung ataupun memperlambat pengosongan lambung. Perbedaan metode pengukuran volume residu gaster pada kedua penelitian sebelumnya berbeda dengan penelitian ini. Penelitian di Afrika menggunakan suction kontinu pada tekanan 200 $\mathrm{mmH}_{2} \mathrm{O}$ dan diaugmentasi tiap 5 menit dengan tangan hingga dirasa lambung kosong dan penelitian di Belgia menggunakan ultrasonografi. Hasil penelitian ini menyatakan bahwa volume residu gaster pada pasien COT berat lebih banyak dibanding dengan COT sedang. Hal ini sesuai dengan penelitian yang dilakukan di Cina pada 35 orang pasien dengan COT sedang dan berat yang menyatakan pemanjangan waktu pengosongan lambung lebih banyak terjadi pada pasien wanita, pasien dengan usia lebih tua, dan pasien dengan GCS lebih rendah. ${ }^{4}$ Perubahan volume residu gaster terjadi karena peningkatan sekresi dan perlambatan pengosongan lambung. Sekresi lambung dapat meningkat karena adanya stimulasi vagal, peningkatan histamin, distensi atau regangan pada lambung. ${ }^{14,15}$ Sedangkan faktor yang dapat memperlambat pengosongan lambung yaitu stimulasi simpatis, makanan yang banyak mengandung $\mathrm{H}+$, lemak, dan protein, 
nyeri, kecemasan, stress, penggunaan obat-obatan antimuskarinik, opioid, penggunaan alkohol sebelumnya, stenosis pilorik, obstruksi intestinal dan riwayat vagotomi sebelumnya. ${ }^{14}$

Subjek penelitian ini adalah pasien COT sedang dan berat yang tidak memiliki penyakit penyerta lain dan tidak mendapatkan obat-obatan yang memperlambat pengosongan lambung sehingga hal-hal yang memengaruhi volume residu gaster pada penelitian ini hanya pada sistem aksis otak-gastrointestinal beserta berbagai mediator inflamasi yang dilepaskan akibat terjadinya trauma. Peningkatan katekolamin mengakibatkan vasokonstriksi dan penurunan aliran darah saluran cerna. ${ }^{10,18}$ Semakin tinggi katekolamin yang dilepaskan, semakin rendah perfusi pada sistem gastrointestinal sehingga volume residu gaster akan meningkat. Hal ini mengakibatkan perubahan motilitas, mukosa, dan perlambatan pengosongan lambung yang lebih signifikan dibandingkan pada pasien COT sedang sehingga pada pasien dengan COT berat masih terdapat volume residu lambung hingga jam ke-48.

Berdasarkan uji Spearman antara variabel GCS dan volume residu lambung didapatkan koefisien korelasi (r) antara -0,754 sampai -0,974 dengan $\mathrm{p}<0,05$. Hal ini menunjukkan korelasi signifikan dengan arah negatif yang kuat antara GCS dengan volume residu gaster. Arah korelasi negatif menyatakan hubungan yang terbalik, yaitu makin rendah GCS maka semakin tinggi volume residu gaster yang didapatkan. Keterbatasan pada penelitian ini adalah metode pengukuran volume residu gaster. Beberapa faktor yang memengaruhi hasil penelitian yaitu posisi ujung pipa nasogastrik terhadap cairan lambung. Konfirmasi posisi ujung pipa nasogastrik dengan ultrasonografi diperlukan namun pada penelitian ini tidak memungkinkan karena keterbatasan alat dan kemampuan peneliti. Standar baku yang dilakukan untuk mengukur volume residu gaster adalah dengan pemeriksaan magnetic resonance imaging (MRI). Namun, hal tersebut tidak dapat dilakukan karena keterbatasan biaya dan fasilitas.

\section{Simpulan}

Volume residu gaster pada pasien COT berat lebih banyak dibandingkan dengan pasien COT sedang dan terdapat hubungan antara skor GCS dan volume residu gaster pada pasien COT. Hasil penelitian ini diharapkan dapat memberikan informasi mengenai hubungan volume residu lambung dan GCS pada pasien dengan COT serta dapat digunakan untuk data penelitian selanjutnya dengan metode pengukuran lain seperti USG pada antrum lambung.

\section{Daftar Pustaka}

1. Stutz HR, Charchaflieh J. Postoperative and intensive care including head injury and multisystem sequelae. Dalam: Cottrell JE, Young WL, penyunting. Cottrell and Young's Neuroanesthesia. Edisi. Philadelphia: Mosby Elsevier; 2010, 407-8.

2. Olsen A, Heitz R, Xue H, Aroom K, Bhattarai D, Johnson E, dkk. Effects of traumatic brain injury on intestinal contractility. Neurogastroenterol Motil. 2013;25:593e463.

3. Lucena AFd, Tiburcio RV, Vasconcelos GC, Ximenes JDA, Filho GC, Graca $\mathrm{RVd}$. Influence of acute brain injuries on gut motility. Rev Bras Ter Intensiva. 2011;23(1):96-103.

4. Kao C-H, Lai S-PC, Chieng P-U, Yen T-C. Gastric emptying in head-injured patients. Am J Gastroenterol. 1991;93(7):1108-12.

5. Ott L, Young B, Phillips R, McClain MC, Adams L, Dempsey R, dkk. Altered gastric emptying in the head-injured patient: relationship to feeding intolerance. J Neurosurg. 1999;74:738-41.

6. Singh S. Neurogastroenterology: gastrointestinal dysfunction from the window of acute brain injury. Int J Stud Res. 2013;3:1-4.

7. Bansal V, Constantini T, Kroll L, Peterson C, Loomis W, Eliceiri B, dkk. Traumatic brain injury and intestinal dysfunction : uncovering 
the neuro-enteric axis. J Neurotrauma. 2009;26:1353-9.

8. Choi HA, Jeon S-B, Samuel S, Allison T, Lee K. Paroxysmal sympathetic hyperactivity after acute brain injury. Curr Neurol Neurosci Rep. 2013;13:370-80.

9. Fernandez-Ortega JF, Baguley IJ, Gates TA, Garcia-Caballero M, Quesada-Garcia JG, Prieto-Palomino MA. Catecholamines and paroxysmal sympathetic hyperactivity after traumatic brain injury. J Neurotrauma. 2017;34:109-14.

10. Takala J. Determinants of splanchnic blood flow. Br J. Anaesth. 1997;77:50-8.

11. Blaser AR, Malbrain MLNG, Starkopf J, Fruhwald S, Jakob SM, Waele JD, dkk. Gastrointestinal function in intensive care patients: terminology, definition, and management. Recommendation of the ESICM Working Group on Abdominal Problems. J Intensive Care Med. 2012.

12. Hurt RT, McClave SA. Gastric residual volumes in critical illness: what do they really mean? Crit Care Clin. 2010;26:481-90.

13. Krakau K, Omne-Pontén M, Karlsson T, Borg J. Metabolism and nutrition in patients with moderate and severe traumatic brain injury: a systematic review. Brain Injury. 2006;20(4):345-67.
14. Jolliffe DM. Practical gastric physiology. Contin educ anaesth crit care pain. 2009;9(6):173-7.

15. Guyton AC, Hall JE. Secretory Function of Alimentary Tract. Textbook of Medical Physiology. Edisi ke-11. Philadelphia: Elsevier Saunders; 2006, 91-807.

16. Utne JB, Moshal M, Downing J, Spitaels $\mathrm{J}$, Stiebel R. Fasting volume and acidity of stomach contents associated with gastrointestinal symptoms. Anaesth. 1977;32:749-52.

17. Putte PVd, Vernieuwe L, Jerjir A, Verschueren $\mathrm{L}$, Tacken M, Perlas A. When fasted is not empty: a retrospective cohort study of gastric content in fasted surgical patient. Br. J. Anaesth. 2017;118(3):363-71.

18. Gelman S, Mushlin PS. Catecholamineinduced changes in the splanchnic circulation affecting systemic hemodynamics. Anesth. 2004;100:434-9.

19. Hang C-H, Shi J-X, Li J-S, Wu W, Li W-Q, Yin H-X. Levels of vasoactive intestinal peptide, cholecystokinin and calcitonin gene-related peptide in plasma and jejunum of rats following traumatic brain injury and underlying significance in gastrointestinal dysfunction. World J Gastroenterol. 2004;10(6):875-80. 